\title{
MODEL KONSTRUKSI KOGNITIF METAPHORA KEWIRAUSAHAAN: PENDEKATAN KONSEPTUAL
}

\author{
Sulastri \\ ZakariaWahab \\ Management, Faculty of Economics, Universitas Sriwijaya \\ Veronica Varbi \\ Faculty of Social Science of Sriwijaya University \\ Sulastri2310@gmail.com
}

\begin{abstract}
Entrepreneurial knowledge is a taxonomic knowledge with complex and extensive metaphor. Its complexity and breadth requires construct simplification to achieve the effectiveness of the cognitive goals that can be guided as a learning outcome. The aim of this research is to produce a conceptual model on the cognitive entrepreneurial knowledge in learning process in higher education. The cognitive construction model is focused on important variables of entrepreneurship such as (a) opportunities recognition, (b) opportunities exploitation (c) innovation, (d) proactive, and (e) risk taking as the main construct variable in entrepreneurship. Conceptual study that concluded that to do cognitive construction from a learning process, 5 aspects are required: (1) content of what will be interpreted; (2) type of representation that will be reflected and explained; (3) referent, the background of representation of the meaning of content; (4) relatedness, the relationship between content and context and (5) the interaction between content, representation, referent and relatedness in forming intentionality. The cognitive construction process will reach it means if intentionality is formed as the goal of learning activity. Proposition of knowledge cognitive construction model gives implication on the future empirical studies as a part of taxonomy and the body knowledge of entrepreneurship.
\end{abstract}

Keywords: Cognitive construction, opportunities introduction, opportunities exploitation, innovation, creativity, proactive, and risk taking.

\begin{abstract}
Abstrak: Pengetahuan kewirausahaan merupakan taksonomi yang memiliki konstruk yang kompleks dan luas. Kompleksitas dan keluasan pengetahuan kewirausahaan membutuhkan penyederhanaan konstruk untuk mencapai efektivitas pada sasaran kognitif yang dapat dipedomani sebagai learning outcome. Tujuan artikel ini untuk memodelkan secara konseptual bagaimana konstruk dan proses kognitif pengetahuan kewirausahaan dalam pembelajaran pada level pendidikan tinggi. Model konstruksi kognitif difokuskan pada variabel penting kewirausahaan antara lain (a) pengenalan peluang, (b) eksploitasi peluang (c) inovasi (d) proaktif dan (e) risk taking sebagai variabel utama yang menjelaskan konstruk kewirausahaan. Kajian konseptual menyimpulkan bahwauntuk melakukan konstruksi kognitif dari suatu proses pembelajaran dibutuhkan (1) konten apa yang akan dimaknai, (2) jenis representasi seperti apa yang dapat merefleksikan dan dijelaskan dalam dunia nyata, (3) referent, apa yang melatar belakangi terjadinya representasiterhadap makna konten (4) bagaimana konten berhubungan dengan konteks (relatedness) (5) bagaimana terjadinya interaksi antara konten, representasi, referent dan relatedness sehingga membentuk
\end{abstract}


intensionalitas. Proses konstruksi kognitif menjadi bermakna jika terbangunnya intensionalitas sebagai sasaran pembelajaran. Model proposisi konstruksi kognitif kewirausahaan memberi implikasi terhadap penelitian empirik yang akan datang sebagai bagian dari taksonomi dan body of knowledge kewirausahaan.

Kata Kunci : Konstruksi kognitif, pengenalan peluang, eksploitasi peluang, inovasi, proaktif, dan risk taking.

\section{PENDAHULUAN}

Studi tentang kewirausahaan merupakan studi yang sangat dinamik dan berkembang. Hal ini ditunjukkan dengan semakin banyaknya buku literatur tentang kewirausahaan (Jonsson,Sara, 2015;Raphael, Nancy \& Gold, Smith, Marshall, 2010; Kiesner, Fred, 2010;Cannon,Tom. 2006).Demikian juga dengan berbagai penelitian yang menjelaskan keragaman konstruk kewirausahaan baik pada level individual(Tucker, et al 2016) institusional maupun publik(Raymond J. March and Adam G. Martin 2016;Campbell, Noel and Witcher, Marcus 2015;Kiesner, Fred2010; Georgellis, Y. and Wall, H.J., 2004)dan berbagai konstrukenterprenurship (Russell dan Miller, 2014; Act, Zoltan, 2012;Cardow,A. 2006).Sementara kajian pada level individual lebih menekankan pada proses perilaku bagaimana terbentuknya intensionalitas orientasi entrepreneurial sebagai proses kognitif. Beberapa peneliti menunjukkan model-model kognitif digunakan untuk menguji intensionalitas sebagai "planned behavior" (Wu, LingFe,and $\mathrm{Li}$, Jun, 2011, Ajzen, I. (1991)diantaranya untuk mengembangkan imajinasi manajerial (Kirby.D.A. 2004), social cognitive career dengan self efficacy(Segal, G. et all, 2007),entrepreneur mind (Jonsson,Sara, 2015; Aimar, Thiery, 2011)entrepreneurial factor (Bolton, Bill and Thomson Jhon, 2004), entrepreneur action (Cannon,Tom, 2006) entrepreneurial processs(Wu, LingFe, dan Li, Jun, 2011, Pruthi, Sarika, 2015; Kiesner, 1973)entrepreneurship cognitive, dan entrepreneurship and social contruct (Russel, Kyle Turner. T dan Miller, Crook, Alex 2014; Wang, Qingfang, 2013).

Dalam konteks pembelajaran kewirausahaan, sangat disadari bahwa domain area pengetahuan melibatkan berbagai disiplin ilmu ekonomi, sosial, psikologi, politik, dan manajemen (Linden, 2015;Noseleit, 2013; Klapper, 2013; Rusu, S., et al, 2012; Forje, 2009; Mintrom dan Norman, 2009).Hubungan kewirausahaan dengan berbagai disiplin ilmu ditunjukkan dengan semakin berkembangnya terminologi kewirausahaan seperti social-entrepreneurship (Pruthi, Sarika 2012; Alex, 2006)technopreneurship (Lee, 2010, Link, dan Siegel, 2007). Intrapreneurship(Tuominen, K. 2012; Taylor, B 2003) dan women enterprenrenur(Maria, Bogren., Yvonne, and Friedrichs, 2016;Sullivan, Diane M, and Meek, 2012). Keluasan dan keragaman pengetahuan memberi implikasi terhadap ekstensifikasi field of research sebagai pengembangan body of knowledge, termasuk dalam konteks kewirausahaan.

Kompleksitas dan tidak sederhananya dunia kewirausahaan masih menjadi perdebatan kajian yang menarik, terutama untuk menjawab kebutuhan dunia pendidikan yaitu, bagaimana generalisasi karakteristik pendidikan kewirausahaan pada tingkat pendidikan tinggi.Bagaimana pendidikan kewirausahaan dapat meningkatkan kesadaran untuk menjadikannyasebagai karir wirausaha dan bagaimana program pendidikan kewirausahaan mampu memodelkan proses belajar dan sasaran belajarnya. 
Kewirausahaan merupakan ide yang sangat kompleks, memiliki banyak makna, dan bagaimana memastikan bahwa setiap orang akan mengetahui tentang apa yang dibicarakan tentang berbagai makna tersebut (Karin and Anders, 2007) Beberapa peneliti mengkritik bahwa proses kewirausahaan tidak hanya bagaimana menghasilkan rencana bisnis, menciptakan bisnis baru, atau manajemen bisnis usaha kecil, akan tetapi juga lebih pada upaya membentuk prilaku.Penelitian akhir-akhir telah menunjukkan bahwa proses enterprenurial lebih dihubungkan dengan proses kognitif sebagai entrepreneurial behaviour(Ali Hajizadeh, Mohammad Reza Zali Zali, 2016;Adomako, Samuel, et al 2016; Jonsson,Sara, 2015; Aimar, Thiery, 2011).

Beberapa peneliti juga menunjukkan bahwa proses kognitif memiliki keterbatasan dan kesulitan dalam pembelajaran, karena merupakan prediksi terhadap perubahan perilaku. Misalnya bagaimana mengkonstruksikan kegigihan, optimisme, nilai-nilai kepercayaan, mengenal peluang dalam proses kognitif. Hal ini juga sebagai faktor kontingensi denganadanya perbedaan gaya kognitif dan proses kognitif yang merupakan bagian penting dari perubahan perilaku seperti berpikir, merasakan dan melakukan tindakan(Adomako, Samuel, et al 2016;Alexandros, Kakouris, 2016).Tantangan pembelajaran kewirausahaan saat ini adalah bagaimana menempatkan isu proses konstruksi kognitif terhadap transformasi pengetahuan kewirausahaan sebagai learning outcome dan bagaimana learning outcome dipersepsikan dalam pendidikan kewirausahaan (Hytti dan Seikkula, 2010).

Konstruk kewirausahaan telah diperkenalkan sebagai metaphora (Todd H. Chiles 2013; Esi A.Elliot, Yazhen, et all 2015;Johan, Gaddefors, 2007; Ian, Fillis, Ruth, and Rentschler, 2008; Cardow, 2006) Cardow diantara peneliti yang membedakan istilah entrepreneur sebagai "noun", entrepreneurship sebagai "verb" dan entrepreneurial sebagai "adjective"(Cardow, A, 2006). Sementara peneliti lainnya menggunakan istilah "entreprenurial orientation" (EO), yang menggambarkan perilaku entrepreneurial untuk merespon lingkungan dengan teknologidan ketidakpastian; (Kirby,D. A, 2004)menggunakan teknologi baru terhadap kecenderungan pasar dan menilai potensi baru menggunakan teknologi baru terhadap kecenderungan pasar dan menilai potensi baru (Lumpkin, Cogliser, \& Schneider, 2009), menggunakan konsep yang terdiri dari innovation, pro-activeness and risk-taking(Lumpkin, G.T. \& dess. GG. 1996, 2005) kemampuan untuk menciptakan produk/jasa baru melalui inovasi, proaktif sebagai karakteristik enterprenur untuk mengantisipasi peluang yang akan datang, risk taking pada situasi ketidak pastian (Kraus et al, 2016; Mahmood, R., \& Hanafi, N. 2013),proactive, innovative, and risk taking(Wiklund, 1999);mengembangkan peluang bisnis baru dalam lingkungan teknologi tinggi (Corbett, A. C. 2002)menciptakan kreativitas dan perubahannya(Kirby, D. A, 2004). Elemen lain sebagai proses enterprenurial adalah opportunity recognition, attribution, self-efficacy, creativity and innovation(Cannon, Tom, 2006).

Uraian di atas menunjukkan bahwa konstruk kewirausahaan merupakan konstruk yang kompleks, terutama jika ditranformasi kedalam dunia pendidikan pada level pendidikan tinggi, yang tidak semua perguruan tinggi memiliki pengajar dan pengetahuan dosen yang cukup. Karena umumnya para pengajar berasal dari monodisiplin ilmu yang ada di program studinya.Disamping itu keragamankonstruk kewirausahaan, yang melibatkan beberapa disiplin ilmu seperti ilmu ekonomi, manajemen, bisnis, psikologi, dan sosial, berdampak pada kesulitan untuk membangun 
sense of meaning dan sense of teachingdalam proses pembelajaran. Sebagaimana dalam tulisan (Berglund, H. and Wennberg, 2006) menunjukkan terdapat perbedaan kreativitas antara murid pada pendidikan teknik dan pendidikan bisnis.Oleh karena itu dibutuhkan model konstruksi kognitif secara sederhana dan mudah dipahami secara universal yang dapat memberi kontribusi bagi pengajar maupun peserta didik untuk lebih mudah mengevaluasi sasaran belajarnya.Hal ini merupakan tantangan bagi dunia pendidikan dalam pengembangan proses pembelajaran, yang umumnya mata kuliah kewirausahaan ditawarkan pada berbagai disiplin ilmu namun program studi tertentu yang memiliki keterbatasan tenaga pengajar secara holistik untuk memahami dunia wirausaha.

Walaupun telah banyak penelitian yang mengkaji tentang validitas konstruk, intensionalitas namun masih sedikit yang membahas bagaimana konstruk tersebut dikonstruksi sebagai model pembelajaran untuk mencapai sasaran belajarnya. Atas dasar pemikiran ini maka penting untuk membuat model konstruksi kognitif konstruk kewirausahaan yang disebut dengan metaphora. Model ini sebagai bentuk untuk memprediksi perilaku dalam pencapaian sasaran belajar.Oleh karena itu penting menempatkan bagaimana konstruksi kognitif terhadap variabel pengenalan peluang, eksploitasi peluang, inovatif, kreatif, proaktif dan risk taking sebagai dimensi penting kewirausahaan yang umumnya disebut dengan orientasi entreprenurial. Tulisan ini akan mengembangkan proposisi yang mengintegrasikan konsep kognitif sebagai bagian dari teori perilaku kognisi terhadap elemen yang akan dikonstruksi sebagai "konten" dengan "proses kognitif". Proses kognitif yang terdiri dari konstruk yang akan dikonstruksi sebagai proses berpikir, bentuk semantik yang mampu merefleksikannya, apa yang menjadi referentnya dan bagaimana kontekstualnya (relatedness) dan apa yang menjadi "planed behavior", dalam hal ini dimaknai sebagai intensionalitas. Dengen model ini akan lebih mudah menentukan arah proses pembelajaran dalam menentukan evaluasi kognitif sebagai sasaran pembelajaran. Disamping itu melalui proposisi ini, akan lebih mudah menentukan arah penelitian empirik terhadap determinan kewirausahaan.

\section{KAJIAN TEORI}

Konstruksi Kognitif. Ilmu kognitif sebagai ilmu interdisiplin yang mempelajari tentang pikiran (yang melibatkan philosophy, psychology, linguistic, artificial intelligence, robotics dan neuroscience(Friedenberg dan Silverman, 2006, pp 2-3).Konstruksi kognitif disebut juga sebagai pengolahan informasi (sebagai input) oleh pikiran yang menghasilkan transformasi informasi, informasi ini dapat disimpan di dalam memori atau keluar sebagai output dalam bentuk bahasa atau perilaku phisik, sebagai representasi kognitif. Representasi dapat dianalogikan sebagai alat untuk membandingkan pada situasi yang sama. Mengutip dari (Friedenberg dan Silverman, 2006 p.3), sebagaimana dinyatakan (Harthhorne, Wiss \& Burk 1931-1958)menyatakan ada empat aspek representasi yang sangat penting (1) representation bearer, sebagai manusia atau komputer yang akan merealisasikan representasi. (2) representasi harus memiliki arti (content) sesuatu yang dapat direpresentasikan sebagai referent atau "grounded" (3) representasi memiliki hubungan dengan "referent" nya (relatedness) (4) representasi harus dapat diinterpretasikan oleh beberapa interpreter. Representasi dapat berbentuk simbol, disebut juga sebagai representasi mental. Representasi mental manusia khususnya untuk linguistic disebut dengan semantic. 
Makna suatu representasi diturunkan dari hubungan antara representasi dan tentang apa yang disebut dengan intentionality. Intentionality berarti mengarahkan sesuatu objek. Intentionality paling tidak memiliki dua properti yaitu (1) isomorphism yaitu kesamaan struktur antara representasi dengan referent. (2) memiliki hubungan antara input dan output terhadap dunia nyata. Representasi intensional harus dipicu oleh referent yang berhubungan dengannya. Konsekuensinya aktivitas suatu representasi seperti berpikir tentang sesuatu menyebabkan perilaku atau tindakan yang ada hubungangannya dengan referent. Hubungan input dan output disebut dengan appropriate causal relation. Bahasa adalah simbol representasi mental, yang dipresentasikan dalam konsep verbal, dan aturan yang merupakan elemen kata yang dikombinasikan dan ditransformasikan dalam bentuk bahasa disebut dengan syntax. (Paul, Thagard,2000) menyatakan dalam mind paling tidak memiliki (1) concept, proposition, rules, dan analogies.

Proses pembelajaran merupakan proses kognisi sebagai sensor input untuk tujuan "transformation, reduced, elaborated, stared, recovered, used"(Baron, R.A. and Ward, T.B, 2004), dan proses kognisi sangat berhubungan dengan intuisi dan analitikal misalnya intuisi dalam kemampuan membaca peluang pasar. Hal inilah yang membedakan antara satu orang dengan lainnya sehingga kognisi merupakan isu sentral dalam entrepreneurship, karena apa yang diimaginasikan yang membedakan perbedaan yang akan datang.Ide sebagai proses imaginasi dan gaya kognitif individual pada gilirannya akan berpengaruh terhadap entrepreneurial intention(Molaei, et al, 2014). Contoh lain misalkan bahwa salah satu ciri wirausaha adalah high risk taker, namun beberapa penelitian menunjukkan dalam realitasnya, sebahagian pengusaha cenderung risk averse atau pada posisi moderately risk taker.Demikian juga untuk membangun perilaku menjadi inovatif, kreatif dan risk taker, serta dapat mengeksploitasi peluang pasar, dibutuhkan strategi belajar dan inovasi dalam kurikulum, dan inovasi dalam kurikulum berdampak pada perlunya pengembangan metode pengajaran dan evaluasi belajar terhadap konteks pendidikan kewirausahaan(Hedner, T. 2011 Dugassa, T.G. 2012).Kurikulum, konten dan metode pembelajaran merupakan instrumen penting dalam proses pembelajaran yang diaplikasikan pada berbagai bidang ilmu (O'byrne dan Nicholas, 2015; Loertscher, 2014; Zohrabi, 2011; Harris dan Koehler, 2009; Horndan Banerjee, 2009; Vartulidan Rohs, 2008;Nygaard dan Hermansen, 2008).Beberapa penelitian telah menunjukkan bahwa pendidikan merupakan variabel intermediasi yang menjelaskan hubungan antara kewirausahaan dengan pertumbuhan ekonomi, sebagaimana dinyatakan oleh (Bahmani, et all,2012) bahwa kewirausahaan tidak berdampak langsung pada pertumbuhan ekonomi akan tetapi melalui pendidikan. Pendapat yang sama dikatakan oleh (Florea dan Florea, 2013), yang menjelaskan bahwa program pendidikan dan pelatihan kewirausahaan telah memberi kontribusi terhadap pembangunan ekonomi. Demikian juga dengan penelitian (Chimucheka, T,2014) menunjukkan terdapat hubungan kewirausahaan dengan pendidikan untuk meningkatkan usaha kecil dan peranan pendidikan kewirausahaan pada negara berkembang untuk mengkonstruksi program kewirausahaan (Mastura, Jaafar, et al 2008; Richard, Mandel, and Erik Noyes, 2016; Farhangmehr et. al, 2016). Hampir semua negara telah menempatkan pendidikan dan pelatihan kewirausahaan sebagai variabel penting yang dapat meningkatkan pembangunan sosial dan ekonomi negara dan telah memasukkan kedalam kurikulum pendidikan tinggi (Oguntimehin dan Nwosu, 2014; Lourenço dan Taylor, 2013;Dugassa, 2012; Fan dan Qiu, 2013). Uraian di atas telah menunjukkan 
pendidikan kewirausahaan memberikan kontribusi penting untuk pembangunan ekonomi, oleh karena perlu didukung dengan proses pembelajaran yang tepat melalui konstruksi kognitif yang relevan dan sesuai antara kebutuhan dunia bisnis yang dinamis dengan dunia pendidikan.

Secara umum learning outcome dapat dikelompokkan menjadi tiga kategori umum yaitu cognitive, skill and affective(St-Jean, E \& Audet,J., 2012). Kognitif merupakan elemen utama dalam proses transfomasi pengetahuan, dan menyempurnakannya menjadi ketrampilan dan perilaku. Proses kognitif merupakan proses sosial dan Taxonomy Bloom's merupakan model popular yang digunakan sebagai instrumen untuk menentukan learning objective dan peralatan evaluasi dalam proses pembelajaran pada berbagai bidang studi sebagai evaluasi kognitif (Adams, 2015; Athanassiou dan Harvey, 2003;Kastberg, 2003;Krathwohl,David R. 2002), mengikuti "Taxnonomy Bloom Revised" menuliskan bahwa konstruksi kognitif dikembangkan menjadi dua dimensi "noun" dan "verb", nounmemberikan dasar untuk dimensi pengetahuan (knowledge) dan verb sebagai bentuk dari dimensi proses kognitif. Dimensi pengetahuan (cognitive knowledge) dikelompokkan atas 4 kategori yaitu (a) Factual knowledge (b) Conceptual knowledge (c) Procedural Knowledge dan (d) Metacognitive Knowledge. Sedangkan proses kognitif meliputi remember, understand, apply, analyze, evaluate and create (Leach, 2007; Krathwohl . David R., 2002).

Tulisan ini mendukung (Krathwohl . David R., 2002)yang membedakan dimensi pengetahuan dengan dimensi proses dalam konstruksi kognitif. Penempatan struktur pengetahuan secara terorganisir mendukung efektifitas dan efisiensi transformasi pengetahuan secara kognitif. Hal ini didasarkan pertimbangan keterbatasan sumberdaya (waktu, tenaga pengajar) untuk mencapai sasaran belajar sesuai dengan profil lulusan. Oleh karena itu sangatlah tepat jika menempatkan model konstruksi kognitif sebagai bagian dari sasaran belajar (learning oucome) khususnya pada level pendidikan tinggi.

Metaphora kewirausahaan. Entrepreneurship sebagai proses analisis, evaluasi dan eksploitasi peluang dengan menciptakan produk atau jasa baru(Scott, S,\& Venkataraman, S., 2000).Sementara (Cardow, A,2006) mengklasifikasikan istilah entrepreneur sebagai "noun"; enterperenurship sebagai "verb" dan enterprenurial sebagai "adjective", yang dikonstruksi dalam lingkungan akademik, sehingga mampu menjelaskan metaphorikal inovatif, kreatif, proaktif, risk dan uncertainty dalam berbagai disiplin ilmu seperti ekonomi, sosiologi, psikologi dan manajemen. Enterpereneurial diartikan sebagai proses kebebasan individual untuk menciptakan bisnis melalui inovasi dan kreativitas (Hisrch, R.D., Peters, M.P. and Shepherd, D.A. 2005), termasuk pengembangan usaha baru dalam bisnis yang sedang berjalan. (Timmons, J.A. and Spinelli, S. 2004; Link, A. N., \& Siegel, D. S. (2007)mendukung Schumpeter yang melibatkan elemen inovasi dan kreativitas dalam menjelaskan enterpereneurship. Lumpkin dan Dess mendefinisikan Enterperenurial orientation "to process, practice and decision making activites that lead to new entry dan inti dari EO adalah competitive aggressiveness, innovativness, proactiveness, risk taking, and autonomy(Lumpkin and Dess, 1996, 136). Berdasarkan pendapat dari beberapa peneliti di atas dapat disimpulkan, bahwa konstruk kewirausahaan tidak hanya sebagai variabel laten dengan indikator tertentu, akan tetapi lebih pada suatu dimensi yang memiliki metaphora luas dengan berbagai konstruk yang mendampinginya sebagai perumpamaan, analogi, terminologi, 
reifikasi, asumsi dan sejenisnya. Representasi kognisi sebagai hasil dari proses pengolahan informasi dapat berupa representasi digital, representasi analog dan representasi proposisi (Friedenberg dan Silverman, 2006).

Dalam tulisan ini dilakukan dengan pendekatan deduktif untuk mengembangkan proposisi, dengan cara mengintegrasikan konsep-konsep dari beberapa penulis terdahulu. Konsep merupakan bentuk dasar dari representasi mental yang dapat berupa abstraksi ide. Konsep dapat dihubungkan satu sama lain dengan cara yang kompleks. Hubungan antar konsep disebut dengan proposisi. Proposisi merupakan hubungan antar konsep, model umum proposisi dapat disajikan dalam bentuk :

[hubungan antar elemen]([elemen subjek], [elemen subjek])

Proposisi dapat disajikan dalam bentuk (a) production rule (b) declarative knowledge (c) procedural knowledge (Friedenberg \& Silverman, 2006). Propsosisi yang disajikan dalam tulisan ini adalah berbentuk declarative knowledge.Secara konseptualtulisan ini menempatkan hubungan antara metaphora kewirausahaan dan konstruksi kognitif sebagaiinteraksi antara konten dan klasifikasi pengetahuan, serta proses kognisi. Secara konseptual hubungan tersebut ditunjukkan pada Gambar1.

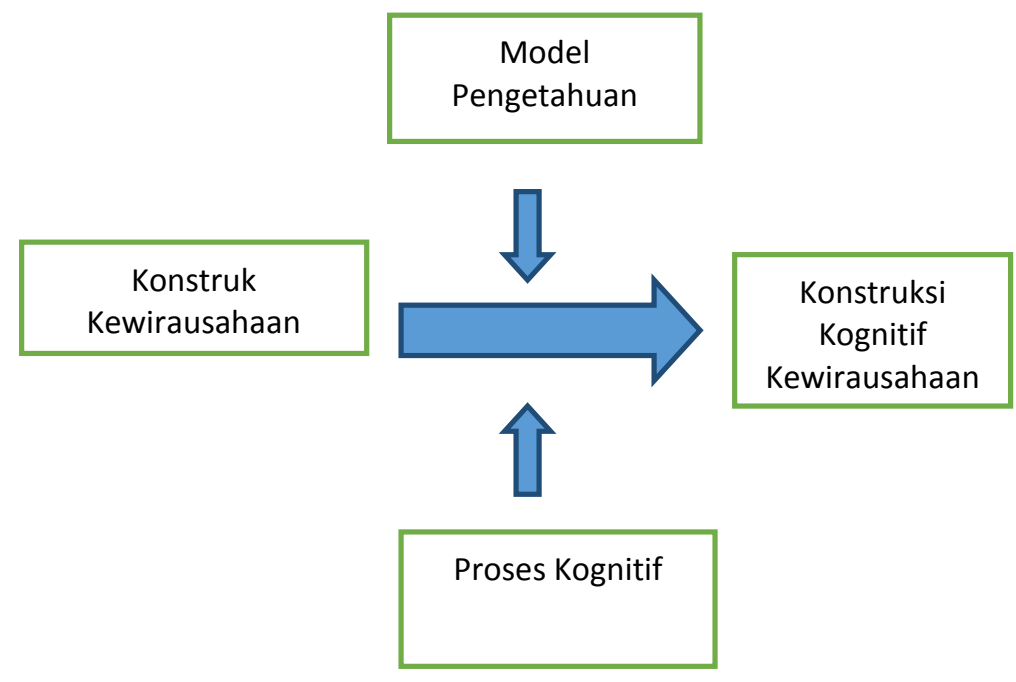

Gambar: 1. Proses Konstruksi Kognitif Kewirausahaan Sumber : dikembangkan oleh peneliti 2016

Gambar 1 menjelaskan suatu konstruk membutuhkan referent atau groundedsehingga konstruk memiliki sense of meaning.Hubungan antar referent dibutuhkan untuk memberi penguatan secara kontekstual.Hubungan antar referent dalam hal ini disebut dengan relatedness. Secara rinci model konstruksi kognitif kewirausahaan dijelaskan di bawah ini.

Model Konstruksi Kognitif Metaphora Kewirausahaan. Sebagai mana telah dijelaskan di atas bahwa kewirausahaan merupakan sebuah metaphora yang dapat dijelaskan dengan keragaman konstruk diantaranya entrepreneurial orientation yang meliputi yaitu(a) pengenalan peluang (b) eksploitasi peluang (c) inovasi, (d) proaktif dan 
(e) risk,(Esi A, Elliot and Yazhen 2015; Ian, Fillis, Ruth, and Rentschler. 2008; Cardow, A. 2006; Lumpkin And Dess, 1996), menginterpretasikan metaphoraentrepreneurship dengan beberapa konstruk antara lain: autonomy, inovativness, creative, agresivness, and risk takingsebagai entrepreneurial orientation.Model konstruksikognitif akan dijelaskan melalui pengembangan proposisi.

Konstruksi Kognitif Opportunity Recognition(OR). Opportunity Recoqnition (OR) merupakan elemen penting dalam domain kewirausahaan (Ali Hajizadeh, et al. 2016; Wang 2013; Shane, 2000). Entrepreneur adalah orang yang mampu untuk mengidentifikasi, mengevaluasi dan mengeksploitasi peluang (Shane, S, 2000).Entrepreneur dapat memiliki cara yang berbeda antara satu dengan lainnya dalam kemampuannya untuk mempersepsikan dan mengeksploitasipeluang. Sehingga pendekatan OR adalah mengapa, kapan dan bagaimana setiap orang mampu untuk menjajaki peluang sementara yang lainnya tidak (Shane and Venkaraman, 2000)Beberapa peneliti telah menunjukkan bahwa konsep peluang, merupakan kata kunci dalam konstruk kewirausahaan, yang dapat diklasifikasikan atas (a) opportunity recognition dan (b) opportunity exploitation(Singh, R, P, 2001).Penelitian ini mendukung (Scott, S., \&Venkataraman, S. 2000), bahwa opportunitiesrecognition dan opportunities exploitation dua konstruk yang berbeda. Peneliti lainnya memperkenalkan sebagai "opportunity discovery" sebagai elemen penting dalam proses kewirausahaan dan penciptaan bisnis (Ardichvili et al., 2003; Baron, R.A., 2006).Sementara Nosella et al., menyebutnya dengan "exploration" and exploitation opportunity untuk menjelaskan praktek rekonfigurasi dan adaptasi terhadap perubahan ekstrenal dan kecenderungan internal yang muncul secara kontinue (Nosella et al, 2012)istilah lainnya dengan opportunity formation dalam social entrepreneurship, Korsgaard, Steffen (2011).

Pengenalan terhadap peluang sangat terkait dengan kemampuan kognitif individu (Arentz, J., et al, 2013;Baron, R.A. 2006;Alsos, G. A., \& Kolvereid, L, 1999).. Sejalan dengan (Ardichvili et.al (2003) bahwa proses "opportunity recognition" dimulai dengan "prior knowledge" yang dapat dikelompokkan atas "special interest" dan "knowledge of industry". Perbedaan setiap indidividu dapat menyebabkan identifikasi peluang yang berbeda karena kepemilikan akan informasi sebagai prior knowledge (pengalaman, aktivitas pekerjaan, pekerjaan yang berhubungan dengan teknologi, pelatihan, status sosial dan aktivitas perjalanan, dan lainnya) yang berbeda satu dengan lainnya (Fiet, J. O, 1996, 2007).Sejalan dengan (Renko,Shrader, \& Simon, M. 2012). yang menyatakan bahwa marked and technological knowledge memiliki peran dalam "recognizing entreprenurial opportunities".Prior knowledge juga meningkatkan probabalitas identifikasi peluang dalam sistem pasar untuk pengembangan produk (Tang et all, 2012). Penulis lainnya menunjukkan adanya hubungan positif antara individual prior knowledge dengan OR dan mengklasifikasikan atas (a) prior knowledge of market (b) prior knowledge ways to serve markets (c) prior knowledge of customer problems(Arentz et. al, 2013).Faktor yang mempengaruhi efektifitas opportunityrecognition, muncul dari serangkaian sumber daya informasi dan difasilitasi oleh karakteristik kognitif yang dibentuk dari "prior knowledge" dari pengalaman pekerjaan, pendidikan, dan lingkungannya, interaksi antara prior knowledge dengan karakteristik kognitif sebagai konstruk yang menjelaskan entreprenurial opportunity recognition(Ali Hajizadeh, et al, 2016).Sejalan dengan peneliti lainnya yang menyatakan bahwa karakteristik kognitif 
yang dipresentasikan oleh entrepreneurial alertness dan entrepreneurial learning adalah sebagai konsep utama dalam domain entrepreneurship dan opprtunity recognition(Tang et al., 2012; Corbett, 2007).Dari uraian di atas dapat ditarik kesimpulan bahwa proses kognisiterhadap konstruk eksploitasi peluang, merupakan proses keterampilan berpikir untuk melakukan sintesis dan mengorganisasikan informasi untuk mengidentifikasikan peluang sebagaimana mereka melakukan investigasi, sebagai cara memandang informasi sebagai proses pengetahuan.

Sementara sebelumnya dalam ekonomi neoklasik menjelaskan bahwa peluang merupakan adanya pemanfaatan dari ketidaksempurnaan dan membawanya ke keseimbangan pasar, pengusaha akan lebih menghabiskan waktu untuk mencari informasi dan mengarahkannya pada peluang baru (Gaglio,2004;Renko, M, et all, 2012)menyatakan bahwa peluang dalam ekonomi neoklasik digunakan sebagai adanya kebutuhan pasar dan bagaimana cara untuk memuaskan kebutuhan pasar. Secara ekonomi, konstruk ini digunakan untuk menjelaskan penawaran dan permintaan dalam model keseimbangan. Sehingga peluang dianggap sebagai cara untuk menjawab ketidak sempurnaan pasar, teori ini menggangap bahwa setiap orang dapat mengambil peluang.Pendapat ini dikritik oleh beberapa peneliti, karena tidak semua orang mampu mengakses informasi dalam kondisi asymmetric information, dan terjadi information gap, sehingga hanya sebahagian orang yang mampu mengidentifikasikan peluang dan sebagian menemukan kegagalan (Neergaard, Helle and Ulhøi, 2007).Hal ini sejalan dengan (Barney, Jay, B, et all,2011) dengan pendekatan Resurces Based Viewmasalah dalam OR adalah adalah kewaspadaan entrepreneurial bagaimana membawa dari philosofi ide-ide ke bisnis riil, yang mengalami perubahan.

Konstruk peluang, juga telah populer diperkenalkan dalam domain manajemen stratejik sebagai proses pengambilan keputusan dari analisis faktor eksternal dan internal(Hitt, Michael A, et all, 2001). Proses perumusan strategi sebagai mekanisme kognitif bagi setiap individu untuk memahami motivasi, asumsi, kekuatan dan kelemahan, hal ini merupakan proses metakognisi (Flavell, 1987). Proses ini merupakan proses kognitif pada level analitikal dan sintesis. Beberapa hal yang berhubungan dengan faktor eksternal seperti dalam konteks teknologi.Faktor eksternal memiliki peran yang sangat penting dalam menciptakan peluang, sebagaimana model Porter's Diamond sebagai perspektif kognitif sebagai pendekatan untuk menganalisis, mensintesis, mengorganisasikan informasi terhadap lingkungan industri sebagai pemicu entrepreneur untuk mengidentifikasikan peluang dan menstimulus mindset dalam opportunity recognition(Ozgen et all., 2011a; 2011b). Pengenalan terhadap peluang sangat terkait dengan kemampuan kognitif individu tertentu,telah menguji hubungan antara pembelajaran kognitif, dan pengenalan terhadap peluang, dan menemukan bahwa "tacit knowledge" adalah penting dalam mengenali peluang pasar dan mendukung untuk memberi pencerahan kognitif kedalam penelitian pengenalan terhadap peluang(Baron, R.A and Ward, T.B, 2004; Shane, 2000; Lumpkin and Lichstenstein, 2005).Persepsi individual terhadap peluang juga tergantung pada siapa, dimana mereka bertempat tinggal dan apa yang mereka milliki(Halonen, R, 2004).

Dari uraian di atas menunjukkan ada perbedaan persepektif pendekatan teori ekonomi dengan pendekatan psikologi dan sosiologi, untuk memaknai peluang. Dimana dalam persepektif ekonomi (Kirznerian) lebih kepada orientasi pasar sebagai "market pull" dan pendekatan sosial berorientasi pada "prior knowledge" yang dominan sebagai 
technological knowledge representasi dari "science push" (Schumpeterian). Sementara pendapat lain menyatakan OR juga merupakan proses interaksi antara kapabilitas individual sebagai prior knowledge dengan faktor eksternal sebagai sumber peluang yaitu (technological change, political regularly change, social dan demographic change(Shane, S, 2000),sebagai faktor lingkungan dari proses penjajakan asymmteric information. Sejalan dengan (Ardichvili, J, et. All, 2003) bahwa proses "opportunity recognition" dimulai dengan "prior knowledge" yang dapat dikelompokkan atas "special interest" dan "knowledge of industry". Identifikasi suatu masalah merupakan starting point yang krusial dalam pengenalan peluang, tetapi tetap sebagai penggerak adalah jiwa enterprenurial yang mendorong individual atau kelompokuntuk mengambil tindakan sesuai dengan "sense of urgency" (Audretch, David B,2015, p. 64).Sehingga konstruk OR masih menjadi perdebatan dalam konstruksi kognitif.

Dalam kajian tulisan ini mengemukakan bahwa pemaknaan terhadap OR sebagai prior knowledge dibangun dari pendekatan kognitif, untuk membangun keterampilan berpikir, yang dimulai dari analitikal, sintesis dan evaluatif yang distimulasi oleh pengalaman sebagai informasi untuk menghasilkan keputusan intuitif. Proses ini terjadi pada level individual sebagai proses pengetahuan (knowledge) apakahmetacognitive knowledgeatau tacit knowledge atau strategic kmowledge sebagai proses intuitif. Pendekatan kognitif akan menjelaskan bagaimana seorang wirausaha berpikir, memiliki alasan, dan memiliki, untuk mengidentifikasikan penciptaan nilai melalui peluang pasar.Berdasarkan dua pendekatan berbasis sumber daya pengetahuan dan orientasi pasar maka dapat disusun proposisi:

\section{Proposisi :1 \\ Konstruksi kognitif opportunity recognition, $($ konten $)=f($ interaksi pengetahuan dengan lingkungan sebagai solusi terhadap masalah melalui investigasi terhadap kesenjangan (representasi); terhadap kebutuhan (push factor) dan ketersediaan pasar(pull factor) (referent); yang memiliki hubungan dengan kondisi geographi, demographi, supplier, pesaing, industri (relatedness); untuk memvalidasi ide/gagasansebagai peluang (intensionalitas).}

Konstruksi kognitif eksploitasi terhadap peluang. Eksploitasi peluang dan pengenalan peluang merupakan konstruk berbeda namun dua konstruk yangtidak dapat dipisahkan dan saling melengkapi, walaupun beberapa peneliti menempatkan isu yang sama dalam penelitian (Jarvis, Lee C, 2016; Schwartz, 2000) dan saat ini telah menjadi field dalam domain ilmu kewirausahaan (Davidsson et al., 2001; Gruber et al., 2015; Renko, M, et al., 2012).Beberapa penulis menunjukkan bahwa eksploitasi peluang merupakan aktivitas entreprenurial untuk mendapatkan keunggulan kompetitif (Yaqing et. al., 2016) dan untuk menjawab new market, new technological atau new productsebagai proses evolusi bisnis yan dinamik sebagai peluang (Cao, Xuanwei et. al, 2014). Untuk ini aktivitas entreprenurial direfleksikan dengan bagaimana entreprenur menggunakan sumber daya secara kreatif untuk mengejar dan merealisasikan nilai peluang (Dutta, D.K.,\& Thornhill, S., 2008; Zampetakis \& Moustakis, 2007). Sementara (Schwartz dan Teach, 2000) yang membedakan opportunity recognition lebih pada faktor eksternal dan opportunity exploitation berhubungan dengan faktor internal. Sejalan dengan (Gruber, R., \& Block, R. A, 2013), menunjukkan bahwa pengalaman sebelumnya, pendidikan, latar belakang 
sosial, mempengaruhi mode of opportunity exploitation. Beberapa peneliti menempatkan eksploitasi peluang sebagai proses start-upbusiness, dari opportunity recognitionmenuju komersialisasi,merupakan tindakan sebagai hasil dari pengenalan terhadap peluang (Frigoto, M., Laura, et. Al, 2014; Fang, C., Lee, J., \& Schilling, M. A. 2010; Lavie, D., Kang, J., \& Rosenkopf, L. 2011).

Eksploitasi peluang membutuhkan teknik, yang dalam literatur bisnis disebut juga strategic model business, atau sejenisnya. Penentuan model strategi bisnis, merupakan model yang kompleks, akan tetapi paling tidak, untuk mengeksploitasi peluang menggunakan teknik dan strategi untuk tujuan meminimalisir risiko dan menciptakan nilai sebagai entrepernurial outcome (Fossen, F.M., and Butter, T.J., 2013). Peranan individual entreprenurial (human capital) dan keputusan terhadap eksploitasi peluang inovasidapat meningkatkan kesuksesan dan memberi kontribusi terhadap kebaruan dan pertumbuhan ekonomi (Chandra et al., 2016). Eksploitasi peluang memiliki hubungan dengan kecenderungan untuk pengambilan keputusan dalam lingkungan ketidak pastian (Fayolle, A., and Linan, F, (2014).Proses ini merupakan perspektif kognitif dalam memprediksi intensionalitas entrepreneur (Jarvis, Lee.C, 2016).Konstruk eksploitasi peluang dapat dijelaskan oleh integrasi antara pengetahuan, pengalaman gaya kognitif dan self efficacy terhadap risiko dan yang lebih penting adalah bahwa proses eksploitasi peluang lebih menekankan pada aspek konstruksi kognitif termasuk personal trait,entreprenurial ambition and goals (Bandura, A. and Locke, E.A. 2003)

Beberapa peneliti menunjukkan bahwa self efficacy merupakan variabel penting dalam pengambilan keputusan terhadap eksploitasi peluang, disamping pengetahuan tentang pasar sebagai bagian dari heuristic entreprenurial (Bryant , Peter, 2007); berbeda dengan (Crockett et.al, 2007), yang menunjukkan bahwa dalam perusahaan korporasi eksploitasi peluang sangat ditentukan pada Top Management Team, sebagai bagian dari otonomi keputusan yang menempatkan area fungsi marketing, akuntansi dan hukum untuk menghasilkan kinerja.

Dari uraian di atas menunjukkan terdapat variabel laten yang menjelaskan eksploitasi peluang sebagai adanya niat untuk "take advantage" sebagi refleksi proses penciptaan nilai, preferensi terhadap resiko, dan self efficacy, untuk masuk dalam bisnis pasar atau produk baru. Maka proposisi dapat disusun:

\section{Proposisi 2}

Konstruksi kognitif eksploitasi peluang (konten) $=f$ (pemanfaatan atau mengambil keuntungan, menciptakan nilai (representasi) berdasarkan sumber daya kapabilitas, pengetahuan, kompetensi, pengalaman(referent 1), preferensi terhadap resiko (referent 2), self efficacy (referent 3), dan kebutuhan prestasi (referent 4); yang berhubungan dengan persaingan,teknologi, penduduk, konsumen, supplier dan lingkungan eksternal lainnya (relatedness)); untuk pengambilan keputusan terhadap strategi bisnis baru, menciptakan bisnis baru, atau pasar baru (intensionalitas).

Konstruksi Kognitif Inovatif. Inovasi didefinisikan sebagai cara untuk mengkombinasikan sumber daya dan eksplorasi peluang untuk menciptakan nilai (Mair and Marti, 2006). Inovasi juga didefinisikan sebagai menciptakan sesuatu lebih baik, lebih efektif, proses dan layanan yang lebih efisien, atau menghasilkan idea atau budaya sebagai hasil dari kreativitas (Crumpton, Michael.A, 2012). Dari perspektif ekonomi 
inovasi merupakan kata kunci dalam proses entrepreneurial, dalam menciptakan keunggulan kompetitif, dengan meningkatkan kapabilitas untuk pertumbuhan bisnis secara berkelanjutan, aktivitas ekonomi dan kesejahteraan negara (O'Connor 2013; Crossan dan Apaydin, 2010). Dalam perspektif sosial, inovasi merupakan konstruk yang menjelaskan proses kewirausahaan, yang dihubungkan dengan penjajakan, evaluasi, eksploitasi dalam proses start-up business, berkreasi, dan tumbuh sebagai dinamisme entrepreneurial (Shane, 2000; Lewrick et al, 2010). Hal ini sebagai proses kognitif yang dibahas dalam program pendidikan sebagai alat untuk mengembangkan sikap entrepreneurial, keterampilan dan kualitas personal yang dirancang untuk memperbaiki kekuatan individual yang dibutuhkan sebagai alat untuk menginisiasi bisnis baru (Fayolle, A. Gailly, B. and Lassas-Clerc, N, 2006; Maritz and Brown 2013).Sehingga hubungan inovasi dan kewirausahaan merupakan sinergi antara ilmu sosial, psikologi dan ekonomi, hal ini juga yang membedakan antara inovasi dalam pendidikan kewirausahaan dengan inovasi pada program pelatihan (Maritz and Donovan 2013). Proses kognitif juga memiliki dampak yang sangat signifikan terhadap social entreprenurship dengan menempatkan inovasi sebagai elemen penting pada social entreprenurship (Xu, Yang, 2016).

Dalam kerangka pedagogik, proses inovasi dapat dilakukan dengan cara (a) belajar secara naratif (b) merencanakan dan memvisualisasikan proses secara eksplisit (c) bekerja secara non verbal melalui refleksi diri dan hands-on methods (d) belajar melalui gambar, simbol dan metaphor (e) belajar melalui praktek lingkungan yang responsif (f) pendekatan inovatif dan interdisiplin secara tidak langsung (g) memodelkan dan merancang/menyusun dari bagian-bagian yang terpisah secara keseluruhan (h) menghubungkan pembelajaran dengan nilai-nilai, kebutuhan dan pengetahuan lokal (Capel, Celin, 2014). Sehingga apa yang ditunjukkan sebagai proses inovasi lebih pada pendekatan proses individual, yang dapat dikembangkan melalui proses pendidikan untuk mengembangkan kapabilitas inovator yang merupakan elemen penting untuk menjelaskan konstruk kewirausahaan. Teori yang paling popular untuk menjelaskan konstruk inovasi secara kognitif adalah "Kirton's adaptive-innovative theory" (1976) yang menjelaskan kecenderungan kognitif dan gaya pengambilan keputusan. Adaptor membutuhkan untuk mengerjakan sesuatu secara lebih baik dan inovator mencari untuk membuat sesuatu secara berbeda. KAI adalah teori yang membantu untuk menjelaskan adanya perbedaan kreativitas diantara anggota tim dan menyatukannya melalui kolaborasi untuk menciptakan inovasi (Stum,K., 2009). Kirton- adaption-innovation theory, pada awalnya teori yang dikembangkan untuk menentukan gaya kognitif dan selanjutnya digunakan dalam berbagai penelitian empirik yang menjelaskan hubungan cognitive style dengan kreativitas dan inovasi serta kolaborasi jejaring terhadap kecenderungan pemecahan masalah (Pettigrew, 1988;Odenwald, 2010;Mudd, 1996).Sebagaimana juga dinyatakan oleh Jablokow and Booth mendefinisikan kesenjangan kognitif (a) perbedaan antara kesulitan terhadap pemecahaan masalah yang spesifik dan kemampuan kognitif pemecahan masalah untuk mencari solusi. perbedaan antara gaya kognitif terhadap pemecah masalah masing-masing (Jablokow dan Booth, 2006). Sebagaimana Kirton's adaptive-innovative model menjelaskan bahwa setiap orang memiliki kapabilitas untuk memecahkan masalahnya sendiri, untuk menjelaskan kecenderungan ini maka diperlukan kolaborasi team work dan leader yang mampu menjembatani cognitive gap, karena adanya perbedaan cognitive ability untuk 
memecahkan masalah. Sehingga model-model pembelajaran untuk konstruksi kognitif inovasi dapat dilakukan dengan metode berbasis pemecahan masalah, atau simulasi. Namun pengembangan metode problem solving sebagai model kognitif entrepreneurship perlu mempertimbangkan perilaku komunikasi untuk meningkatkan adaptasi sebagai upaya pemecahan masalah (Kim, 2006).

Sejalan dengan Schumpeter bahwa inovasi merupakan proses pembelajaran dan sebagai peran sentral untuk mendukung pertumbuhan ekonomi (Galindo at al., 2013). Konstruk inovasi hubungannya dengan kewirausahaan sebagaimana ditunjukkan para peneliti legendaris seperti Schumpeterian's view; bahwa aktivitas kewirausahaan menyiratkan inovasi sebagai pengenalan produk baru, organisasi atau proses menghasilkan suatu proses penghancuran dari status quo, innovator menghasilkan produk baru sebagai perubahan dalam struktur ekonomi. Sementara Kirznerian's view; entrepreneur belajar dari kesalahan masa lalu dan mencoba untuk memperbaikinya, membawanya ke pasar untuk mengambil peluang yang menguntungkan.Berbeda dengan Knight menunjukkan bahwa untuk membawa inovasi ke pasar entrepreneur berhadapan dengan risiko dan ketidakpastian, hal ini sebagai elemen penting untuk menentukan pengambilan keputusan bagaimana reward untuk menutupi risiko(Galindo at al., 2013), enterprenurship selalu diasumsikan sebagai menghasilkan sesuatu yang baru, inovasi baru, berisiko dan profitabel (Dees, 2001; Drucker, 1985; Martin \& Osberg, 2007). Hal ini dikritik dari pandangansocial entreprenurship(Wiseman, Alexander W., 2014).

Uraian di atas menyiratkan bahwa konstruk inovasi merupakan konstruk yang kompleks. Permasalahannya dalam dunia pendidikan adalah bagaimana transformasi kognitif yang dapat membentuk intensionalitas inovasi sebagai refleksi proses pembelajaran kewirausahaan. Sebagaimana ditunjukkan beberapa penelitian proses kognitif inovasi melalui pendidikan menempatkan "theory of planned behavior",yang telah digunakan dalam berbagai konteks, penduduk, area, untuk menilai intension dan perilaku (Ajzen, I, 1991)dan akhir-akhir ini digunakan untuk mengevaluasi program pendidikan kewirausahaan (Fayolle et al., 2006; Souitaris et al.,2007; Florin et al., 2007). Sejalan dengan berbagai pendapat di atas maka penelitian ini menempatkan konstruk inovasi sebagai proses kognitif yang dibentuk dari beberapa variabel laten, sebagai model yang dapat digunakan dalam impelementasi pembelajaran, maupun penelitian empirik untuk menjelaskan pengetahuan kewirausahaan dengan proposisi.

Proposisi : 3

Konstruksi kognitif "inovasi"(konten) = f(pembaharuanterhadap konsep,(referensi 1), produk (referensi 2), layanan (referensi 3), metode (referensi 4), kebijakan (referensi 5), norma (referensi 6), sebagai proses adaptasi terhadap ketidak tepatan (referent 1),ketidak efisisen (referent 2), ketidak efektifan (referent 3), kehilangan waktu (referent 4), ketidak bermanfaatan referent (5), secara kontekstual dalam hal solusi terhadappermasalahan, kebutuhan, kesenjangan, persaingan (relatedness),dan menempatkannya pada perubahan bentuk, ukuran, tahapan, visual, proses, fungsi secara berwujud maupun tidak berwujud untuk tujuan komersialisasi (intensionalitas).

Konstruksi Kognitif Proaktif. Proaktif merupakan salah satu variabel laten dari konstruk entrepreneurship (Lumpkin dan Dess, 1996;Cardow (2006) dan proaktif merupakan karakter perilaku manusia (Salaz, 2012) yang disebut dengan kepribadian proaktif (Prieto, 2010; Prieto, 2011). Konstruk proaktif selalu dibandingkan dengan 
reaktif dalam literatur orientasi pasar untuk menghadapi turbulensi teknologi, intensitas persaingan, maupun ketidak pastian lingkungan eksternal lainnya (Wang, Qingfang,2013).Konstruk proaktif merupakan konstruk kepribadian dan setiap orang memiliki kepribadian proaktif yang berbeda berdasarkan jenis perilaku proaktif, (Bateman dan Michael, 1993), telah menjelaskan terdapat hubungan antara skalaproaktifdan domainkepribadian'Big Five': neurotisisme, extraversion, keterbukaan, keramahan, dan hati nurani. Selanjutnya menunjukkan bahwa skalaproaktif berkorelasidengankebutuhanuntuk berprestasi, kebutuhan untuk dominasi, independensi darisifatekstrakurikuler, memiliki karakter personal terhadap prestasiutama, dan nominasisebagai pemimpin transformasional. Konstrukproaktif memiliki kemampuan untuk memprediksi, berbagaiperilaku.Proaktif dan reaktif memilliki prilaku yang sama sebagai aggressor akan tetapi dibangun dari kognitif yag berbeda. Sementara (Pursoo, 2013) menyatakan bahwa perilaku proaktif dimulai dengan adanya rasa empati terhadap lingkungan yang berdampak pada motivasi belajar, yang pada gilirannya berdampak pada orientasi tujuan. Bahkan perilaku proaktif merupakan proses internalisasi dari nilainilai kegagalan dan sebagai motif pembelajaran (Yamakawa, 2008). Sementara (Marler, 2008) telah menunjukkan bahwa prilaku proaktif masa lalu berdampak pada perilaku masa depan, sehingga karakteristik bio data masa lalu dapat digunakan sebagai alat prediktif perilaku proaktif masa yang akan datang.

Sehingga proaktif merupakan konteks personalitas yang didefinisikan sebagai " $a$ dispositional construct that identifies differences among people in the extent to which they take action to influence their environment" (Bateman and Crant, 1993, p. 103)Sejalan dengan (Prabhu et al.,2012) dengan istilah "propensity to act" yang digunakan sebagai isu sentral terhadap tenant mengapa mereka memilih enterprenurship sebagai karir. (Prabhu et al., 2012).Mahasiswa dengan pribadi proaktif akan lebih suka untuk meraih apa yang dipersepsikan sebagai peluang, sebagaimana diteliti oleh (James, et al.,2016), yang menguji persoalitas proaktif dan persepsi terhadap dukungan universitas berpengaruh positif terhadap niat enterprenurial (James et al., 2016).

Konstruk proaktif dalam kaitannya dengan entrepreneurship dapat dijelaskan bahwa kepribadian proaktif merupakan hasil dari proses adaptasi dan menghasilkan tindakan opportunistic. Sementara tindakan opportunistic dapat berupa gagasan atau ide baru. Sehingga perilaku proaktif dapat menjelaskan konstruk orientasi entrepreneurial. (Prabhu et all., 2012) menemukan terdapat hubungan antara perilaku proaktif personal dengan niat entrepreneurial. Sejalan dengan(Prieto, 2011) dengan studi empiriknya terhadap murid-murid -American and Hispanic juga menemukan bahwa kepribadian proaktif mempengaruhi niat untuk menjadi sosial enterpreneurship. Perilaku proaktif juga sebagai faktor anteseden untuk meningkatkan ide menjadi inovasi (Bjorklundet all., 2013). Sementara pada level organisasional proaktif dikarakterisasikan sebagai opportunity-seeking,danforward-lookingperspectiveuntuk memperkenalkan produk/jasa baru dalam berkompetisi sebagai antisipasi terhadap permintaan yang akan datang. Sementara agresif kompetitif diartikan sebagai intensitas upaya perusahaan untuk lebih unggul dari pesaing industrinya, yang dikarakterisasikan dengan postur offensive yang kuat atau respon agresif untuk menghadapi tindakan kompetitor, dengan kebebasan otonomi sebagai enterprenurial untuk membawanya ke usaha baru (James, et al., 2016).

Tindakan proaktif dapat terjadi pada level individual maupun organisasional sehingga model konstruksi kognitif dapat dikembangkan atas dasar perilaku personalitas 
maupun kerja tim sebagai refleksi organisasional. Konstruksi sikap perilaku proaktif telah dikembangkan dalam proses pembelajaran, sebagaimana (Kiss, 2010) menjelaskan bahwa untuk membangun prilaku proaktif yang dihubungkan tindakan opportunistic, dapat dilakukan melalui model-model pembelajaran business game dan simulasi. Sebagaimana juga (Axline, 2001) dalam tulisannya juga menyatakan bahwa proaktif adalah proses adaptasi dan konstruk yang terukur, demikian juga dalam proses pembelajaran hubungan antara proses dan learning outcome harus dapat terukur. Dalam proses pembelajaran untuk mengembangkan perilaku proaktif dapat dilakukan dengan model pembelajaran team work, misalnya meliputiprosestim produksi, prosespemeliharaantim, strukturtim, danmemoritim. Peran memori dalam pembelajaran tim dapat menggunakanmulti-metode studi kasus yang dapat menstimulan adaptasiproaktifyang tinggidengan karakteristik memiliki orientasi tugas, transparansitindakan, akuntabilitas bersama, saling mendukung, semangat untuk melakukan penyelidikan, kontrolbersama,adanya keterbukaan lingkungan, keseimbangan antarahirarkidantim, memoriyang beradapada individu, dan memoriyang berada pada tim. Berdasarkan uraian di atas maka konstruksi kognitif proaktif dapat dikembangkan dengan proposisi:

Proposisi 4:

Konstruksi kognitif "proaktif"'(konten) = f(perilaku opportunitistic, opportunity-seeking (representasi) atau foward looking sebagai proses internalisasi terhadap respon lingkungan (referent 1) persaingan (referent 2),pasar baru (referent 3) yang berhubungan dengan daya saing (relatedness), untuk proses adaptasi, perlindungan dan responsif baik pada level individual maupun organisasional (intensionalitas).

Konstruksi Kognitif Risk Taking. Risk taking dapat dianalisis pada level individual dan organisasional sebagai proses pengambilan keputusan yang dapat bersifat objektif maupun subjektif (Marshall and Ojiako, 2014; Marshall and Guidi, 2012; Boholm and Corvellec, 2011;Denis, Hilton, 2015) "Risk-taking", didefiniskan oleh sebagai komitmen untuk berusaha dan menerima ide untuk memulai sebuah usaha menjadi aspek yang terintegral dari perilaku entrepreneurial yang tertarik pada elemen risiko maupun ketidakpastian (Mitchell et al. 2004, p. 978). Beberapa peneliti menunjukkan bahwa konstruk risk taking dapat dibedakan atas uncertainty dan risk(Marshall and Ojiako 2014; Galindo at al., 2013; York and Venkataraman, 2010; McMullen and Shepherd, 2006). Uncertainty merupakan ketidak pastian terhadap faktor-faktor yang tidak dapat diperhitungkan,sedangkan risiko merupakan probabilitas yang dapat diperhitungkan (Marshall and Ojiako 2014). Risk takingjuga diartikan sebagai tingkat penerimaan terhadap resiko sumber daya secara beralasan dan menggantikannya dengan biaya kegagalan. "Risiko" dipandang sebagai peluang untuk kebutuhan pertumbuhan dan "pengambilan resiko" dipandang sebagai konsep diri merupakan dimensi utama dalam menentukan kemampuan untuk mengambil resiko (Sweeney, 1985). Dari uraian di atas berbagai cara untuk menjelaskan tentang konstruk risk dan risk takingdan bagaimana proses kognisi dapat diperkenalkan untuk membantu menjelaskan sikap terhadap risiko.

Persepsi terhadap risiko memiliki hubungan dengan pola prilaku terhadap resiko dan persepsi terhadap lingkungan, serta informasi baru yang dapat merubah preferensi terhadap risiko. (Brown, 2005; Bogner, et all., 2000; Lambert, 2011; Petrakis, 2005) 
menunjukkan resiko dipersepsikan oleh pengusaha ditentukan oleh perilaku dan kinerja entrepreneurial. Preferensi terhadap risiko ditentukan oleh kerangka prilaku enterprenurial yang dimediasi oleh faktor lingkungan eksternal dan derajad kebebasan pengusaha yang memiliki kebutuhan akan prestasi sesuai dengan persepsi resikonya. (Dionne, Fluet, dan Desjardins, 2007),dalam penelitiannya menunjukkanhubungan antarapersepsi risikodanperilakupengambilan risikodalam berbagaikonteks, dan menunjukkan bahwa persepsiterhadap risiko mempengaruhi perilakurisiko dan persepsirisikobersifat endogen.(Zhai, dan Suzuki, 2009), meneliti terhadap berbagai negara di Asia menunjukkan terdapat perbedaan karakter kecenderungan toleransi terhadap risiko yang dipengaruhi oleh faktor pendidikan, umur, dan gender.

Risk taking atau keberanian mengambil resiko merupakan konstruksi kognitif dalam proses pembelajaran agar mahasiswa memiliki karakter dalam hal keberanian mengambil resiko. Risiko dapat diklasifikasikan atas (1) strategic risk" yaitu potensi risiko pada saat memasuki usaha yang belum diketahui namun telah menghabiskan relatif sejumlah aset yang besar, (2) personal risk yaitu resiko sebagai tanggung jawab yang dibebankan secara personal terhadap potensi resiko yang akan terjadi (3) social risk resiko yaitu resiko yang diterima secara bersama terhadap orang-orang yang terlibat dalam pengambilan keputusan atau terhadap orang lain sebagai dampak dari keputusan (4) psychology risk yaituresiko yang diterima dalam bentuk perasaan, rasa ketakutan (Gasse, 1982) (4) financial risk yaitu sebagai ukuran reward terhadap risiko atau menghasilkan kesuksesan yang diukur dengan tradeoff risk-return(Pleskac, 2008).

Dari beberapa pendapat peneliti yang menunjukkan bahwa preferensi terhadap resiko merupakan konstruk prilaku sebagai variabel endogen. (Sepúlveda, dan Bonilla, 2011) melakukan studi tentang sikap dan penerimaan terhadap risiko serta pengaruhnya untuk menjadi seorang entrepreneur, yang menemukan bahwa pengalaman kegagalan dalam bisnis tidak berpengaruh pada sikap terhadap risiko untuk mengembangkan bisnis baru. (Saulo,2007) menunjukkan bahwa hubungan gaya kognitif dengan preferensi terhadap resiko memberi kontribusi terhadap entrepreneurialself-efficacy and entrepreneurial intentions. Hasil penelitiannya menunjukkan bahwa individu dengan preferensi terhadap resiko yang tinggi memiliki tingkat intensitas entrepreneurial yang lebih tinggi dan memiliki keyakinan diri terhadap identifikasi peluang, sementara individu dengan preferensi risiko yang rendah memiliki toleransi yang lebih tinggi terhadap keyakinan diri. Individu dengan gaya kognitif intuitif, juga ditemukan memiliki persepsi yang lebih rendah terhadap keyakinan diri yang berkenaan dengan penentuan terhadap hubungan dengan investasi terhadap usaha baru dan memiliki toleransi terhadap ambisiusitasnya. Sejalan dengan (Armstrong dan Hird, 2009) yang menyatakan bahwa entrepreneurcenderung lebih intuitif dan kurang analisis dibandingkan non entrepreneur.Entreprenuer yang lebih intuitif menunjukkan tingkat perilaku pemicu entrepreneurial yang lebih tinggi.

Model pembelajaran konstruksi kognitif tentang preferensi terhadap resiko dapat dilakukan dengan model simulasi, misalnya (Chen, Y, 2001) menggunakan role modellearning dengan single and multiple play gambles untuk mengetahui preferensi terhadap resiko.(Duening, T. N, (2008) menunjukan model untuk mengembangkan kognitif skill on entrepreneurship curriculum design., Salah satunya adalah mengembangkan kemampuan untuk mengelola risiko dengan cara mengelola 
kemampuan emosional untuk mengelola persepsi terhadap risiko, dan kemampuan untuk mengurangi risiko yang sebenarnya melalui tindakan spesifik.

\section{Proposisi 5 :}

Konstruksi kognitif "Risk Taking"(konten) $=f$ (kepenerimaan dan kewaspadaan terhadap resiko secara sadar (representasi) dalam kondisi ketidak pastian terhadap sumber daya (referent), investasi (referent 2),kekayaan (referent 3),pasar (referent 4)yang berhubungan dengan ide gagasan, inovasi, bisnis baru, peluang baru, investasi baru (relatedness) untuk membangun keyakinan diri dalam pengambilan keputusan komersialisasi (intensionalitas).

\section{SIMPULAN DAN SARAN}

Dimensi pengetahuan (knowledge) pembelajaran kewirausahaan, sangatlah luas yang melibatkan berbagai disiplin ilmu, serta taksonomi yang semakin berkembang. Dimensi pengetahuan merupakan proses institutional sedangkan konstruksi kognitif merupakan proses individual yang akan menghasilkan sasaran belajar (learning outcome) dengan tingkat kognitif tertentu sebagai evaluasi pembelajaran. Permasalahannya adalah bagaimana dimensi pengetahuan dikonstruksi secara kognitif untuk mengarahkannya pada learning outcome.

Model konstruksi kognitif yang dikembangkan dalam bentuk proposisi merupakan model penting yang dapat dipedomani dalam pembelajaran kewirausahaan yang memiliki kompleksitas dan keluasan pengetahuan.Model konstruksi kognitif yang telah dikemukakan dalam tulisan ini memberi kontribusi pada domain ilmu kewirausahaan, dan pengembangan body of knowledgedalam penelitian empirik. Model konstruksi kognitif ini dapat digunakan secara universal, sehingga dapat diuji validitas konten (semantik) dan validitasi konstruk, secara empirik.

Model konstruksi kognitifmetaphora kewirausahaan akan lebih membantu pengajar untuk melakukan transfer pengetahuan yang dapat dengan cepat dipahami oleh peserta didik. Pernyataan proposisi sebagai representasi mental dari proses kognitif, sebagai pendekatan untuk membangun intensionalitas.Model ini akan mendorong terjadinya capaian pembelajaran baik dari aspek kognitif, psikomotorik dan afektif, sebagai learning outcomesecara lebih efektif.

Untuk lebih mendorong terjadinya interaksi antara mahasiswa dan pengajar disarankan mengembangkan model ini dalam bentuk pelatihan simulasi, exprimental dan role playing dalam proses pembelajaran.

\section{DAFTAR PUSTAKA}

Acs, Zoltan. J. (2012). The 2012 Global Entrepreneurship And Development Index (GEDI): Perspectives From Americas.

Adams, N. E. (2015). Bloom's Taxonomy Of Cognitive Learning Objectives. Journal Of The Medical Library Association. 103(3); 152-153.

Adomako, Samuel., Albert, Danso, Moshfique.,\& Uddin John Ofori-Damoah (2016),"Entrepreneurs' optimism, cognitive style and persistence", International Journal of Entrepreneurial Behavior \& Research, Vol. 22 Iss 1 pp. 
Aimar,.Thierry (2011), Cognitive Opening and Closing: Toward and Exploration of the Mental World of Entrepreneurship" In Hayek in Mind: Hayek's Philosophical Psychology, Advanced in Austrian Economics, Volume 15, 241-257.

Ajzen, I. (1991), "The theory of planned behavior. Organizational behavior and human decision processes", Vol. 50 No. 2, pp. 179-211.

Alex, Nicholas. (2006). Social Entrepreneurship. (Retrived From: Http://Www.Ebrary.Com /28-9-2015).

Alexandros, Kakouris. (2016). "Exploring entrepreneurial conceptions, beliefs and intentions of Greek graduates", International Journal of Entrepreneurial Behaviour \&amp; Research, Vol. 22 Iss 1 pp. -

Ali Hajizadeh, Mohammad Reza Zali Zali, (2016),"Prior knowledge, cognitive characteristics and opportunity recognition", International Journal of Entrepreneurial Behaviour \&amp; Research, Vol. 22 Iss 1 pp. -

Alsos, G. A., \& Kolvereid, L. (1999). The business gestation process of novice, serial and parallel business founders. Entrepreneurship Theory and Practice, 22(4), 101114

Amstrong, S.J. \& Hird Andrew, (2009), Cognitive Style \& Entreprenurial Drive of New and Mature Business Owner \& Managers, Journal Business Psychology, 24, 419430.

Ardichvili, A., Cardozo, R. and Ray, S. (2003), "A theory of entrepreneurial opportunity identification and development”, Journal of Business Venturing, Vol. 18 No. 1, pp. 105-23.

Arentz, j., Sautet, F. and Storr, V. (2013), Prior Knowledge and Opportunity Identification, Small Business economics, Vol 41 No 2, pp. 461-78.

Athanassiou, N., Mcnett, J. M., dan Harvey, C. (2003). Critical Thinking In The Management Classroom. Bloom's Taxonomy As A Learning Tool. Journal of Management Education 27(5): 533-555.

Auderetsch, David, B., (2015), Everything In Its Place Entreprenurship and the Strategic Management of Cites, regions and States, Oxford University Press, ISBN 978-0$19-935125$.

Axline, S.L. (2001). Proactive Adaptation In ERP Teams. Mechanisms Of Team Learning. Proquest Dissertations And Theses: 403-403 P.

Bahmani, S., Galindo, M., \& Méndez, M. T. (2012). Non-Profit Organizations, Entrepreneurship. Social Capital And Economic Growth. Small Business Economics. 38(3): 271-281.

Bandura, A. and Locke, E.A. (2003), "Negative self-efficacy and goal effects revisited", Journal of Applied Psychology, Vol. 88 No. 1, pp. 87-99

Baron, R.A and Ward, T.B. (2004). The cognitive perspective: A valuable tool for answering entrepreurship's basic "why?" questions. Journal of business venturing: 19,221-239.

Bateman, T. S., \& Michael Crant, J. (1993). The Proactive Component Of Organizational Behavior. A Measure And Correlates. Journal Of Organizational Behavior (19861998). 14(2): 103.

Berglun, H. And Wennberg (2006) Creativity Among Entreprenurship Students Comparing Engineering \& Business Education, International Journal of Contributing Engineering Education Vol 16 No 5 pp 366-79. 
Barney Jay B., Ketchen Jr, David J., and Wright,Mike. (2011). Journal of Management Vol. 37 No. 5, September 2011 1299-1315.

Bjorklund, T., Bhatli, D., and Laakso, M. (2013). Understanding Idea Advancement Efforts In Innovation Through Proactive Behavior. Journal Of Research In Marketing And Entrepreneurship, 15(2): 124-142.

Bogner, F. X., Brengelmann, J. C., \& Wiseman, M. (2000). Risk-Taking And Environmental Perception. Environmentalist. 20(1): 49-62.

Boholm, A. and Corvellec, H. (2011), "A relational theory of risk", Journal of Risk Research, Vol. 14 No. 2, pp. 175-190.

Bolton, Bill and Thomson, John, (2004), Enrepreneurs, Talent, Temprament, Technique, Second Edition, Elsievier, Butterworth, Heinemann, ISBN 6750661283

Brown, S. L. (2005). Relationships Between Risk-Taking Behaviour And Subsequent Risk Perceptions. British Journal Of Psychology. 96: 155-64.

Bryant, Peter. (2007). "Self-regulation and decision heuristics in entrepreneurial opportunity evaluation and exploitation", Management Decision, Vol. 45 Iss 4 pp.

Campbell, Noel and Witcher, Marcus , (2015),"Political entrepreneurship: Jefferson, Bayard, and the election of 1800", Journal of Entrepreneurship and Public Policy, Vol. 4 Iss 3 pp. $298-312$

Cannon, Tom, BSc, (2006) The Entrepreneur's Strategy Guide : Ten Keys For Achieving Market Place Leadership and Operational Excellent, Praeger Publisher, USA Printed

Cao, Xuanwei, Liu, Yipeng, Cao, Chunhui, (2014), Institutional entreprenurs on opportunity formation and exploitation in strategic new industry, International jurunal of emerging Markets Vol 9, No 3 pp. 439-458

Capel, Celine. (2013). Mindfulness, indigenous knowledge, indigenous innovations and entrepreneurship. Noah's Ark Pre School and Childcare Centre, King's Christian College,Gold Coast, Australia. Journal of Research in Marketing and Entrepreneurship Vol. 16 No. 1, 2014 63-83.

Cardow, A. (2006). The Metaphorical Rise Of Entrepreneurship. Departement Of Management And International Business Research Working Paper Series 2006, No 8). Auckland, NZ. Massey University: Departement Of Management And International Business.

Chandra, B.M., Lafuente, E., and Vailant, Y., (2016), Human capital and The Decision to Exploit Innovative Opportunity, Management Decision, vol. 54. Iss7. Pp.-

Chen, Y. (2001). The Role Of Learning In Risk Preferences For Single-And MultiplePlay Gambles. (Order No. 3005701. Columbia University). Proquest Dissertations And Theses: 152-152 P.

Chimucheka, T. (2014). Entrepreneurship Education In South Africa. Mediterranean Journal Of Social Sciences. 5(2): 403-416.construction programme

Corbett, A. C. (2002). Opportunity Recognition: A Learning And Cognitive Approach. Proquest Dissertations And Theses : 185-185 P.

Crockett, Dilene R., Payne, G. Tyge, Jeffrey E. McGee. (2007) "Exploitation of Entrepreneurial Opportunities in the Corporation: An Exploration of FunctionalLevel Support, Decision Autonomy, and Performance" In Entrepreneurial Strategic Processes. Published online: 09 Mar 2015; 33-63. 
Crossan, M.M. and Apaydin, M. (2010), "A multi-dimensional framework of organizational innovation: a systematic review of the literature",Journal of Management Studies, Vol. 47 No. 6, pp. 1154-1191.

Crumpton, Michael A. (2012). "Leading Results Innovation and entrepreneurship". University Libraries, University of North Carolina at Greensboro, Greensboro, North Carolina, USA. The Bottom Line: Managing library finances Vol. 25 No. 3, 2012 pp. 98-101 $q$

Davidsson, P., Low, M. B., \&Wright, M. (2001). Editor's introduction: Low and MacMillan ten years on: Achievement and future directions for entrepreneurship research. Entrepreneurship Theory and Practice, 25(4), 5-16.

Dees, J. G. (2001). The meaning of "social entrepreneurship." Retrieved from http://www.sage global.org/wp-content/uploads/2010/08/Dees_SEdef.pdf. Accessed on July 11, 2013.

Denis Hilton. (2015). "Overconfidence, Trading and Entrepreneurship: Cognitive and Cultural Processes in Risk-taking" In Cognitive Economics: New Trends. Published online: 08 Mar 2015; 225-235.

Dionne, G., Fluet, C., dan Desjardins, D. (2007). Predicted Risk Perception And RiskTaking Behavior. The Case Of Impaired Driving. Journal Of Risk And Uncertainty. 35(3): 237-264.

Drucker, P. (1985). Innovation and entrepreneurship. New York, NY: Harper \& Row

Duening, T. N. (2008). Five Minds For The Entrepreneurial Future. (Retrifed from:Http://Search.Proquest.Com/Docview/192410900?Accountid=31434/14-92016).

Dugassa, T. G. (2012). The Context Of Entrepreneurship Education In Ethiopian Universities. Management Research Review. 35(3): 225-244.

Dutta, D.K., \& Thornhill, S (2008) The Evolution Growth Intentions: Toward a Cognition Based Model, Journal Og Business Venturing, 23 (3), 307-332

Esi A. Elliot, and Yazhen (2015)."A multicultural blend: metaphors, cognitive social capital and multiculturalism", International Marketing Review, Vol. 32 Iss 2 pp. $200-218$

Fan, Y., Zhang, X., \& Qiu, Y. (2013). The State Of Entrepreneurship Education In Universities In Shanghai. China. A Survey From Students' Perspective. Creative Education. 4(2): 92-97.

Fang, C., Lee, J., \& Schilling, M. A. (2010). Balancing exploration and exploitation through structural design: The isolation of subgroups and organizational learning. OrganizationScience, 21, 625_642.

Farhangmehr, Paulo, Gonçalves Maria Sarmento , (2016),"Predicting entrepreneurial motivation among university students: The role of entrepreneurship education", Education + Training, Vol. 58 Iss 7/8 pp. -

Fayolle, A. Gailly, B. and Lassas-Clerc, N. (2006), "Effect and counter-effect of entrepreneurship education and social context on student's intentions", Estudios de Economía Aplicada,Vol. 24 No. 2, pp. 509-523.

Fayolle, A., and Linan, F., (2014), The Future of Research on Entrepreneurial Intentions, Journal Of Business Research, Vol 67 No 5, pp 663-66

Fiet, J. O. (2007), A persepective Analysis of search and Discovery, Journal of Management Studies, Vol 44 No 4 pp 592-611. 
Fiet, J. O. (1996). The informational basis for entrepreneurial discovery. Small Business Economics, 8, 419-430

Flavell, J.H. (1987). Speculations about the nature and development of metacognition. In F.E. Weinert\& R.H. Kluwe (Eds.), Metacognition, motivation and understanding (pp. 21-29). Hillsdale, NJ: Erlbaum

Florea, R., and Florea, R. (2013). Entrepreneurship And Education In European Union Countries : Economy Transdisciplinarity Cognition, 16(2):75-80.

Florin, J., Karri, R., and Rossiter, N. (2007). Fostering entrepreneurial drive in business education: An attitudinal approach. Journal of Management Education , 31 (1), 17 42.

Forje, L. C. (2009). A Historical Development Of Entrepreneurship In The Cameroon Economy From 1960-2007. Journal Of Asia Entrepreneurship And Sustainability. 5(3): 1-16.

Fossen, F.M., and Butter, T.J., (2013), The Returns to Education for Opportunity Entrepreneurs, necessity entrepreneurs and paid emplyees, Economics of Education Review Vol 37, pp. 66-84.

Friedenberg. Jay., and Silverman, Gordon. (2006), Cognitive Science An Introduction to Study of Mind. Sage Publications Inc. ISBN: 1-4129-2.568-1.

Frigotto, M. Laura, Coller, Graziano and Collini, Paolo "Exploration and Exploitation from Start-up to Sale: A Longitudinal Analysis through Strategy and MCS Practices" In Exploration and Exploitation in Early Stage Ventures and SMEs, Technology, Innovation, Entrepreneurship and Competitive Strategy, Volume 14, 149_179

Gaglio, C. M. (2004). The Role of Mental Simulations and Counterfactual Thinking in the Opportunity Identification Process. Entrepreneurship Theory and Practice 28(6): 533-552.

Galindo, , Miguel - Ángel and Picazo , María-Teresa Méndez, (2013),"Innovation, entrepreneurship and economic growth",Management Decision, Vol. 51 Iss 3 pp. $501-514$

Gasse, Y.' (1982). Elaborations on psychology of teh entrepreneur. In C.A.Kent. D.L. Sexton \& K.H. Vesper (Eds) Encyclopedia of Entrepreneurship : 209-223 Englewood Cliffs, NJ: Prentice Hall.

Georgellis, Yannis \& Wall, Howard J., (2004), Entreprenurship and The Policy Environment, The Federal Reserved Bank of ST Louis, Research Division, Wotking Paper.

Gruber, R., \& Block, R. A. (2013). The flow of time as a perceptual illusion. The Journal of Mind and Behavior, 34, 91-100.

Gruber, M., Kim, S.M. and Bribnckmann, J. (2015), What Is An Attractive Business Opportunity An Empirical Study of Opportunity Evaluation Decisions by technologist, manager and entrepreneurs, Startegic Entrepreneurship Journal, Vol 9, No.3, pp. 205-225

Halonen, R. (2004). Users, not necessarily choosers. Design Philosophy Papers, (1) Retrieved from http://search.proquest.com/docview/993138083?accountid=31434

Harris, J., Mishra, P., \& Koehler, M. (2009). Teachers' Technological Pedagogical Content Knowledge And Learning Activity Types: Curriculum-Based Technology 
Integration Reframed. Journal Of Research On Technology In Education, 41(4), 393-416.

Hedner, T. (2011), How To Implement An Innovation And Entrepreneurship Curriculum. Global Focus, 5, 28-31.

Hisrch, R.D., Peters, M.P. and Shepherd, D.A. 2005. Entrepreneurship, Sixth Edition, McGraw Hill/Irwin, New York

Hitt, Michael A and R. Duane, Ireland and Hoskisson, Robert E, 2001 Strategic Management Compeetitivenessand Globalization, South-Western College Publishing.

Horn, E., \& Banerjee, R. (2009). Understanding Curriculum Modifications And Embedded Learning Opportunities In The Context Of Supporting All Children's Success. Language, Speech \& Hearing Services In Schools, 40(4), 406-15

Hytti, U., Stenholm, P., Heinonen, J., \& Seikkula-Leino, J. (2010). Perceived Learning Outcomes In Entrepreneurship Education. Education \& Training, 52(8), 587-606.

Ian, Fillis, Ruth, and Rentschler. (2008). "Exploring metaphor as an alternative marketing language", European Business Review, Vol. 20 Iss 6 pp. 492 - 514

Jablokow, K. W., \& Booth, D. E. (2006). The Impact And Management Of Cognitive Gap In High Performance Produce Development Organizations. Journal Of Engineering And Technology Management, 23 , 313-336.

James, Michael, Ernesto Mustafa, Hernandez, Christopher Mahon and Lai Kei Chee , (2016),"Entrepreneurial Intentions of, university students in an emerging economy: the influence of university support and proactive personality on students' entrepreneurial intention", Journal of Entrepreneurship in Emerging Economies, Vol. 8 Iss 2 pp.

Jarvis, Lee C., (2016), Identification intention and entrepreneurial opportunities: an integrative process model, international Journal of entrepreneurial Behavior \& Research, Vol 22 Iss 2

Johan, Gaddefors. (2007). Entrepreneurial Behaviour \& Research. Metaphor use in the entrepreneurial process, Department of Business Studies, University of Ga“vle, Ga“vle, Sweden: International Journal of Vol. 13 No. 3, 2007 pp. 173-193,

Johnson, Sara , (2015),"Entrepreneurs' network evolution - the relevance of cognitive social capital", International Journal of Entrepreneurial Behavior \& Research, Vol. 21 Iss 2 pp. $197-223$

Karin and Anders. (2007).Constructions of entrepreneurship: a discourse analysis of academic publications. Journal of Enterprising Communities: People and Places in the Global EconomyVol. 1 No. 1, 2007 pp. 77-102 q

Kastberg, S. E. (2003). Using Bloom's Taxonomy As A Framework For Classroom Assessment. The Mathematics Teacher, 96(6), 402-405.

Kiesner, Fred (2010), creating Entrepreneurs making Miracles Happen, World Scientific Publishing Co, Pte, Ltd, Singapore, ISBN 1397898142611-1

Kim, J. (2006). Communicant Activeness, Cognitive Entrepreneurship, And A Situational Theory Of Problem Solving. (Order No. 3222318, University Of Maryland, College Park). Proquest Dissertations And Theses, , 392-392 P.

Kirby, D. A. (2004). Entrepreneurship Education: Can Business Schools Meet The Challenge? Education \& Training, 46(8), 510-519. 
Kiss, A. N. (2010). Opportunistic Adaptation And New Venture Growth: Exploring The Link Between Cognition, Action And Growth. (Order No. 3490059, Georgia State University). Proquest Dissertations And Theses, , 196-N/A.

Klapper, R. G. (2013). Entrepreneurship Education In France: A Perspective Of Theory And Practice. American Journal Of Entrepreneurship, 6(2), 37-54.

Korsgaard, Steffen. (2011),"Opportunity formation in social entrepreneurship", Journal of Enterprising Communities: People and Places in the Global Economy, Vol. 5 Iss 4 pp. $265-285$

Krathwohl . David R. (2002),A Revision Of Bloom's Taxonomy: An Overview (2002) THEORY INTO PRACTICE, Volume 41, Number 4, Autumn 2002Copyright C) 2002 College Of Education, The Ohio State University

Kraus , Sascha, Meier, Fabian and Niemand , Thomas , (2016),"Experimental methods in entrepreneurship research: the status quo", International Journal of Entrepreneurial Behavior \& Research, Vol. 22 Iss 6 pp. -

Lambert, L. (2011). Create A Culture Of Entrepreneurship, Risk-Taking. PR News, $67(38)$

Lavie, D., Kang, J., \& Rosenkopf, L. (2011). Balance within and across domains: The performance implications of exploration and exploitation in alliances. Organization Science, 22, 1517_1538.

Leach, E. (2007). Instruction-Based Action Guidelines Built On Bloom's Revised Framework: Setting Objectives For Entrepreneurship Teaching. Journal Of Small Business And Entrepreneurship, 20(4),

Lee, C. B. (2010). Generating Synergy Between Conceptual Change And Knowledge Building. Human Development, 53(3), 134-152.

Lewrick, M., Omar, M., Raeside, R. and Sailer, K. (2010), "Education for entrepreneurship and innovation: management capabilities for sustainable growth and success", World Journal of Entrepreneurship, Management and Sustainable Development, Vol. 6 Iss. 1, pp. 1-18.

Linden, P. (2015). Entrepreneurship: Theory And Application In A University Arts Management Setting. MEIEA Journal, 15(1), 81-98.

Link, A. N., \& Siegel, D. S. (2007). Innovation, Entrepreneurship, And Technological Change. Oxford, GB: OUP Oxford.

Loertscher, D. V. (2014). Transitioning To Concept-Based Curriculum And Instruction: How To Bring Content And Process Together. Teacher Librarian,41(4), 42-42,63.

Lourenço, F., Taylor, T. G., \& Taylor, D. W. (2013). Integrating "Education For Entrepreneurship" In Multiple Faculties In "Half-The-Time" To Enhance Graduate Entrepreneurship. Journal Of Small Business And Enterprise Development, 20(3), 503-525.

Lumpkin And Dess 1996, Clarifying The Entrepreneurial Orientation Construct And Linking It To Performance , Academy Of Management Review, 2(1): 135-172

Lumpkin, G. T., Cogliser, C. C., \& Schneider, D. R. (2009). Understanding and measuring autonomy: An entrepreneurial orientation perspective. Entrepreneurship Theory and Practice, 33(1), 47-69.

Lumpkin, G.T \&Dess , G.G. (2005).Linking Two Dimension Entrepreneurial To Firm Performance : The Moderating Role Of Environment And Industry Life Cycle, Journal Of Business Venturing, 16(5): 429-451 
Lumpkin, G.T. \& Lichetenstein, B.B. (2005) The Role Organizational Learning in The Opportunity Regognition Process, Entreprenurship Theory and Practice 29 (4) 451472

Mahmood, R., \& Hanafi, N. (2013). Entrepreneurial Orientation and Business Performance of Women-Owned Small and Medium Entreprises in Malaysia: Competitive Advantage as a Mediator. International Journal of Business and Social Science, 4(1), 82-90.

Mair, J and Marti, I. (2006), "Social entrepreneurship research: A source of explanation, prediction, and delight", Journal of World Business, 41(1): 36.

Maria, Bogren, Yvonnevon, and Friedrichs. (2016). "Trust-building processes in women's entrepreneurship". Journal of Enterprising Communities: People and Places in the Global Economy. Vol. 10 Iss 1 pp. 70 - 100.

Maritz, Alex and Jerome, Donovan, 2013. Entrepreneurship and innovation Setting an agenda for greater discipline contextualization. Swinburne University of Technology, Melbourne, Australia; Education + Training Vol. 57 No. 1, 2015 . 7487

Maritz, P.A. and Brown, C. (2013), "Illuminating the black box of entrepreneurship education programs", Education + Training, Vol. 2 No. 3, pp. 234-252.

Marler, L. E. (2008). Proactive Behavior: A Selection Perspective. (Order No. 3308058 , Louisiana Tech University). Proquest Dissertations And Theses, , 146.

Marshall, A. and Guidi, M. (2012), "The idea of a sociology of risk and uncertainty: insight from Pareto", in Femia, J.V. and Marshall, A. (Eds), Vilfredo Pareto: Beyond Disciplinary Boundaries, Ashgate, Farnham

Marshall, Alasdair and Ojiako, Udechukwu. (2014). A realist philosophical understanding of entrepreneurial risk-taking. Society and Business Review Vol. 10 No. 2, 2015 pp. 178-193

Martin, R.L., \& Osberg, S.R. (2015), "Two keys to sustainable social enterprise", HarvardBusiness Review 93(5), 86-94, 2015.

Mastura, Jaafar., Abdul, Rashid., and Abdul, Aziz. (2008),"Entrepreneurship education in developing country", Journal of Engineering, Design and Technology, Vol. 6 Iss 2 pp. $178-189$

McMullen, J. and Shepherd, D. (2006), "Entrepreneurial action and the role of uncertainty in the theory of the entrepreneur", Academy of Management Review, Vol. 31 No. 1, pp. 132-152.

Mintrom, M., \& Norman, P. (2009). Policy Entrepreneurship And Policy Change. Policy Studies Journal, 37(4), 649-667.

Mitchell, R.K., Busenitz, L., Lant, T., McDougall, P., Morse, E. and Smith, J. (2004), "The distinctive and inclusive domain of entrepreneurial cognition research", Entrepreneurship Theory andPractice, Vol. 28 No. 6, pp. 505-518.

Molaei , Roya, Zali, Mohammad Reza, Mobaraki, Mohhammad Hasan and Farsi, Jahngir Yadollahi, (2014), The impact of entrepreneurial ideas and cognitive style on students entrepreneurial intention, Journal of Entrepreneurship in Emerging Economies Vol. 6 No. 2, 2014 pp. 140-162

Mudd, S. (1996). Kirton's A-I Theory: Evidence Bearing On The Style/Level And Factor Composition Issues. British Journal Of Psychology, 87, 241. 
Neergaard , Helle and Ulhøi, John Parm (2007), Handbook Of Qualitative Research,Methods In Entrepreneurship, Edward Elgar Publishing Limited Glensanda House Montpellier Parade Cheltenham Glos GL50 1UA, ISBN, 9781 843768357

Noseleit, F. (2013). Entrepreneurship, Structural Change, And Economic Growth. Journal Of Evolutionary Economics, 23(4), 735-766.

Nygaard, C., Højlt, T., \& Hermansen, M. (2008). Learning-Based Curriculum Development. Higher Education, 55(1), 33-50.

O'byrne, D., Dripps, W., \& Nicholas, K. A. (2015). Teaching And Learning Sustainability: An Assessment Of The Curriculum Content And Structure Of Sustainability Degree Programs In Higher Education. Sustainability Science, 10(1), 43-59.

O'Connor, Christopher D. (2013) "Engaging Young People? The Experiences, Challenges, and Successes of Canadian Youth Advisory Councils" In Youth Engagement: The Civic-Political Lives of Children and Youth. Published online: 08 Mar 2015; 73-96.

Odenwald, K. (2010). Transforming Liberal Education Through The Imagination: Critical-Creative Thinking In Higher Education Curriculum And Pedagogy. (Order No. 3403276, City University Of New York). Proquest Dissertations And Theses, , 218-N/A.

Oguntimehin, Y. A., P., \& Nwosu, J. C. (2014). Building A Sustainable Development Through Entrepreneurship Education In Nigeria. Kuwait Chapter Of The Arabian Journal Of Business And Management Review, 3(7), 278-285.

Ozgen C, Nijkamp P, Poot J (2011a) Immigration and innovation in European Regions. IZA discussion paper 5676. IZA Institute for the Study of Labour, Bonn

Ozgen C, Nijkamp P, Poot J (2011b) The impact of cultural diversity on innovation: evidence from Dutchfirm-level data. IZA discussion paper 6000. IZA Institute for the Study of Labour, Bonn

Paul, Thagard. (2000). Mind: Introduction to Cognitive Science, Cambridge, MA:MIT Press

Petrakis, P. E. (2005). Risk Perception, Risk Propensity And Entrepreneurial Behaviour: The Greek Case. Journal Of American Academy Of Business, Cambridge, 7(1), 233-242.

Pettigrew, A. C. (1988). Creativity And Cognitive Style Of Creativity: A Description Of Graduate Nursing Faculty And Construct Validation Of The Kirton AdaptionInnovation Theory. (Order No. 8822138, Indiana University School Of Nursing).

Pleskac, T. (2008). Decision making and learning while taking sequential risks. Journal of Experimental Psychology: Learning, Memory, and Cognition, 34(1), 167-185.

Prabhu, V. P., Mcguire, S. J., Drost, E. A., \& Kwong, K. K. (2012). Proactive Personality And Entrepreneurial Intent. International Journal Of Entrepreneurial Behaviour \& Research, 18(5), 559-586.

Prieto, L. C. (2010). Proactive Personality And Entrepreneurial Leadership: Exploring The Moderating Role Of Organizational Identification And Political Skill. Academy Of Entrepreneurship Journal, 16(2), 107-121. 
Prieto, L. C. (2011). The Influence Of Proactive Personality On Social Entrepreneurial Intentions Among African-American And Hispanic Undergraduate Students: The Moderating Role Of Hope. Academy Of Entrepreneurship Journal, 17(2), 77-96.

Pruthi, Sarika. (2012). "Process of Social Entrepreneurship in India: The Case of Goonj" In Social and Sustainable Enterprise: Changing the Nature of Business. Published online: 08 Mar 2015; 1-23.

Pursoo, T. (2013). Predicting Reactive And Proactive Relational Aggression In Early Adolescence As A Function Of Individual Differences In Machiavellianism, Empathy, And Emotion Regulation. (Order No. NR98632, University Of Ottawa (Canada)). Proquest Dissertations And Theses, , 166.

Raphael, Nancy \& Gold Smith, Marshall, 2010, The Enterperneurs's Guide to Mastering the Inner World of Business, Santa Barbara California, USA, ISBN 9700-31338002-0.

Raymond J. March and Adam G. Martin. (2016). Department of Agricultural and Applied Economics: Texas Tech University, Lubbock, Texas, USA. Journal of Entrepreneurship and Public Policy Vol. 5 No. 2, 2016 pp. 201-220

Renko, M., Shrader, R. C., \& Simon, M. (2012). Perception of entrepreneurial opportunity: A general framework. Management Decision, 50(7), 1233-1251.

Richard, Mandel, Erik, Noyes. (2016),"Survey of experiential entrepreneurship education offerings among top undergraduate entrepreneurship programs", Education + Training, Vol. 58 Iss 2 pp. $164-178$.

Russell, Crook, Alex, Miller, and Kyle, Turner, T. (2014)."Construct Measurement in Social Entrepreneurship: A Review and Assessment" In Social Entrepreneurship and Research Methods. Published online: 10 Oct 2014; 1-18.

Rusu, S., Isac, F., Cureteanu, R., \& Csorba, L. (2012). Entrepreneurship And Entrepreneur: A Review Of Literature Concepts. African Journal Of Business Management, 6(10), 3570-3575.

Salaz, J. C. (2012). Adolescent Perceptions And Beliefs Of Proactive-Reactive Aggression Explored Through The Social Information Processing Model Of Aggression. (Order No. 3517589, The University Of New Mexico). Proquest Dissertations And Theses, , 150. Ret

Saulo, D. B., Gerhardt, M. W., \& Kickul, J. R. (2007). The Role Of Cognitive Style And Risk Preference On Entrepreneurial Self-Efficacy And Entrepreneurial Intentions. Journal Of Leadership \& Organizational Studies, 13(4), 86-104.

Schwartz, R., \& Teach, R. (2000). Entrepreneurship research: An empirical perspective. Entrepreneurship Theory and Practice, 24(3), 77-81.

Scott, S., \&Venkataraman, S. (2000). The promise of entrepreneurship as a field of research. Academy of Management.the Academy of Management Review, 25(1), 217-226.

Segal, G.Schoenfeld, J.\& Borgia, D. (2007). Which Classroom-Related Activities Enhance Students' Entrepreneurial Interests And Goals?: A Social Cognitive Career Theory Perspective. Academy Of Entrepreneurship Journal, 13(2), 79-98.

Sepúlveda, J.,P., \& Bonilla, C. A. (2011). The Attitude Toward The Risk Of Entrepreneurial Activity: Evidence From Chile. Academia, (46).

Shane, S. (2000), " Prior knowledge and the discovery of entrepreneurial opportunities", 
Shane, S. and Venkataraman, S. (2000), "The promise of entrepreneurship as a field of research", Academy of Management Review, Vol. 25 No. 1, pp. 217-226.

Singh, R. P. (2001). A Comment On Developing The Field Of Entrepreneurship Through The Study Of Opportunity Recognition And Exploitation. Academy of Management.The Academy Of Management Review, 26(1), 10-12.

Souitaris, V., Zerbinati, S. and Al-Laham, A. (2007), "Do entrepreneurship programmes raise entrepreneurial intention of science and engineering students? The effect of learning, inspiration and resources", Journal of Business venturing, Vol. 22 No. 4, pp. 566-591.

St-Jean, E., \& Audet, J. (2012). The Role Of Mentoring In The Learning Development Of The Novice Entrepreneur. International Entrepreneurship And Management Journal, 8(1), 119-140.

Stum, K. (2009). Whole-building shutdown tests. Consulting - Specifying Engineer,46(5), 24-29. Retrieved from http://search.proquest.com/docview/220596862? accountid= 31434

Sullivan, Diane M. and Meek, William R. (2012), Journal of Managerial PsychologyVol. 27 No. 5, 2012 pp. 428-458

Sweeney, B., Bingham, R, Amos, R., Petty A, \& Cole, R (1985). Toxicity of bone marrow in dentists exposed to nitrous oxide. British Medical Journal, \$91, 567569.

Tang,J., Kacmar, M., Busenitz, L., (2012), Alertness in the pursuit of new opportunities, Journal Of Business venturing, Vol 27. N0 1, pp 41-62.

Taylor, B. (Ed.). (2003). Corporate Governance And Entrepreneurship. Bradford, GBR: Emerald Group Publishing Ltd

Timmons, J.A. and Spinelli, S. 2004. New Venture Creation:Entrepreneurship for the 21 st Century, Sixth Edition, McGraw Hill/Irwin, NewYork

Todd H, Chiles, (2013),"The kaleidic world of entrepreneurs", Qualitative Research in Organizations and Management: An International Journal, Vol. 8 Iss 3 pp. 276 307

Tucker, Reginald L, Graham, H, and Lowman, Louis, D. Marino. (2016). "Dark Triad Traits and the Entrepreneurial Process: A Person-Entrepreneurship Perspective" In Research in Personnel and Human Resources Management. Published online: 30 Jun 2016; 245-290.

Tuominen, K. (2012). Development Models - BEF : Intrapreneurship - Excellence Criteria - BEF. Turku, FIN: Benchmarking.

Vartuli, S. A., \& Rohs, J. (2008). Selecting Curriculum Content That Stimulates Thought. Early Childhood Education Journal, 35(5), 393-396.

Wang, Qingfang. (2013). "Constructing a multilevel spatial approach in ethnic entrepreneurship studies". Department of Geography and Earth Sciences, UNC Charlotte,Charlotte, North Carolina, USA. International Journal of Entrepreneurial Behaviour \& Research Vol. 19 No. 1, 2013 pp. 97-113

Wiklund, J. (1999). The sustainability of the entrepreneurial orientation-performance relationship. Entrepreneurship Theory and Practice, 24(1), 37-48. Wiklund, J. (1999). The sustainability of the entrepreneurial orientation performance relationship. Entrepreneurship Theory and Practice, 24(1), 37-48. 
Wiseman, Alexander W. (2014). Internationally comparative approaches to innovation and entrepreneurship in education international educational innovation and public sector EntrepreneurshipInternational Perspectives On Education And Society, Volume 23, 3_31.

Wu, Ling Fe \& Li, Jun (2011), Perceived value of entrepreneurship A study of the cognitive process of entrepreneurial career decision, Journal of Chinese Entreprenurship vol 3 no 2, pp 134-146.

$\mathrm{Xu}$, Yang, (2016),"Entrepreneurial social capital, cognitive orientation and new venture innovation", Management Research Review, Vol. 39 Iss 5 pp. -

Yamakawa, Y., Peng, M. W., \& Deeds, D. L. (2008). What drives new ventures to internationalizefrom emerging to developed economies? Entrepreneurship Theory and Practice,32(1), 59_82.

Yaqing, Baoshan Ge., Chen, Sun Yong, and Gao, Yang (2016), Opportunity Exploitation and Resource Exploitation: an integrative Growth Model For Entrepreneurship, Internet Research, Vol 26 Iss 2 pp.-

York, J. and Venkataraman, S. (2010), "The entrepreneur - environment nexus: uncertainty, innovation, and allocation”, Journal of Business Venturing, Vol. 25 No. 5, pp. 449-463.

Zampetakis, L., A., \& Moustakis, V., (2007) Entreprenurial Behaviour in The Greek Public Sector, International Journal of entreprenurail Behaviour \& Research, 13(1), 19-38.

Zhai, G., \& Suzuki, T. (2009). Risk Perception In Northeast Asia. Environmental Monitoring And Assessment, 157(1-4), 151-67.

Zohrabi, M. (2011). An Investigation Of Curriculum Elements For The Enhancement Of The Teaching-Learning Process. Higher Education Studies, 1(1), 67-78. 